\title{
Individual and Societal Dimensions of Security
}

\author{
PinAR Bilgin \\ Department of International Relations, Bilkent University, Turkey
}

\begin{abstract}
Despite the prevalence of state-based approaches to security studies during the Cold War, alternative ways of thinking about securityfocusing on the individual and society - also developed during this time period. However, in the post-Cold War era the primacy of the state in considerations of security has come under increasing challenge from a variety of perspectives. In this essay, the development of the study of individual and societal dimensions of security is traced and discussed against the background of the end of the Cold War. The first part of the essay examines the evolution of thinking about individual and societal dimensions of security during the Cold War. The second part focuses on the post-Cold War revival in thinking about these aspects of security. The essay concludes by considering the future of world politics conceived of as a "risk society" and the implications for individual and societal dimensions of security.
\end{abstract}

The concept of security has traditionally been related more to states than to people. Since the seventeenth century, when the current system of states began to emerge, international security has been understood and practiced with reference to the needs and interests of states. Although, in its early origins, the state was conceived as an instrument for producing security for its citizens, it became the subject of security with the establishment and retrenchment of the state-system. Notwithstanding the alternative conceptions of security that have always existed, this statebased and external-directed conception of security has prevailed and shapes the practices of governments. Critical voices calling for the importance of protecting human beings or the global environment aside, twentieth-century thinking and practices concerning security were characterized by this way of thinking. The emphasis the United Nations has put on sovereignty and the inviolability of territorial boundaries can be viewed as an indication of the institutionalization of this approach.

Even though state-based conceptions of security have taken precedence, alternative ways of thinking that give priority to individual and societal dimensions of security have also been proposed. In this essay, the evolution of the study of individual and societal dimensions of security is traced and discussed against the background of the end of the Cold War. The first part looks at the development of thinking about the individual and societal dimensions of security during the Cold War by examining three major contributors to the dialogue on this topic and their ideas, namely, the Commission on Global Governance and its conception of "common security," academic peace research and their proposal regarding "stable peace," and Third World security approaches. The second part of the essay focuses on the post-Cold War revival in thinking about security by identifying key issues 
and approaches around which debates have been structured, including "whose security?" "primary referents," "security as emancipation," "insecurity dilemma," "societal security," "human security," and "agents of security." The essay concludes by considering the future of world politics conceived of as a "risk society," and the implications of this consideration for individual and societal dimensions of security.

\section{Cold War Thinking}

\section{Common Security}

Mikhail Gorbachev's adoption of the precepts of common security not only made the headlines but also brought this idea to the forefront of world politics during the 1980s. Common security is based on the notion that security must be sought and maintained not against one's adversaries but with them. This approach is necessary because states, in searching for security, end up making themselves more insecure by enhancing their military power, which in turn causes others to feel insecure and increase their military power in response: the classic security dilemma (Herz 1950; Wheeler and Booth 1992). Common security seeks to mitigate the security dilemma by organizing policies concerning security in coordination with others to maximize mutual as opposed to unilateral security.

The need for such coordinated activity was heightened in the Cold War environment by the imminent threat of global nuclear catastrophe. Olaf Palme, in his introduction to the report of the Independent Commission on Disarmament and Security Issues (1982:ix) titled Common Security: A Programme for Disarmament, wrote:

\footnotetext{
Our alternative is common security. There can be no hope of victory in a nuclear war, the two sides would be united in suffering and destruction. They can survive only together. They must achieve security not against the adversary but with him. International security must rest on a commitment to joint survival rather than on a threat of mutual destruction.
}

By putting common security into practice, Gorbachev changed the Soviet approach to arms control, accepting sufficiency rather than seeking parity with the United States (Allison 1991). Accordingly, the Soviet Union was able to make unilateral concessions to reduce their arms, which in turn took away the West's threat and paved the way for the end of the Cold War.

\section{Stable Peace}

Although it was students of common security who emphasized the need for global security and pointed to its nonmilitary dimensions, academics involved in peace research laid the intellectual groundwork for these ideas by producing studies that focused on individuals and social groups as referents for security. Students of peace research also suggested alternative security practices (that is, nonmilitary, nonzero sum, nonviolent approaches), putting special emphasis on peace education and the role of the intellectual (Garrison and Phipps 1989; Dunn 1991; Rabinowitch 1997).

Works by Johan Galtung and Kenneth Boulding were critical in urging us to consider individual and societal dimensions of security. According to the maximal approach introduced by Galtung (1969), peace did not just mean the absence of war; it was also related to the establishment of conditions for social justice. In making this point, Galtung distinguished between personal and structural violence. The latter is defined as those socioeconomic institutions and relations that oppress human beings by preventing them from realizing their potential. Violence, for Galtung (1996:197, emphasis in the original), is all those "avoidable insults to basic 
human needs, and more generally to life, lowering the real level of needs satisfaction below what is potentially possible." Moreover, he defined cultural violence as those mechanisms that render acceptable both direct violence (as in killing, repression, and delocalization) and structural violence (as in exploitation, penetration, and marginalization). Thus, Galtung turned both the use of violence and the ways in which violence is legitimized by the society into a subject of study. By adopting a broader definition of violence and an approach that focused on human needs, he and other students of peace research shifted the focus away from the state and the military dimension of security to individuals and social groups and their needs.

Galtung underlined the futility of trying to achieve peace without tackling the structural causes of the insecurity of individuals and social groups as well as states. Distinguishing between negative and positive peace, he argued that peace defined merely as the absence of armed conflict is negative peace. Positive peace, maintained Galtung (1996:32), means the absence of both direct (physical) violence and indirect (structural and cultural) violence. He emphasized that to attain positive peace, it is not enough to seek to eliminate violence; existing institutions and relations must be geared toward the enhancement of dialogue, cooperation, and solidarity among peoples coupled with a respect for the environment.

Kenneth Boulding's (1978) conception of stable peace was invaluable in emphasizing that peace maintained through the use of threat and force cannot be stable. He explained stable peace by comparing it with unstable peace (that is, peace maintained through threatening mutual annihilation, namely nuclear deterrence). Unstable peace is defined as a condition in which no real expectations exist that peace (understood as the mere absence of armed conflict) will be maintained in the future. Stable peace, in contrast, exists when two sides learn how to make peace by creating trusting relationships that disarm people's minds as well as their institutions. Such relationships, argued Boulding, can stand the stress of crises that threaten to tear them apart because everyone has a firm expectation regarding the nature of future relations.

Another contribution of peace researchers was their emphasis on the increasing inappropriateness of established ways of thinking about security given the security concerns of individuals and social groups in the West. The practices of Western European peace movements during the 1970s and 1980s served to drive this lesson home (see Kaldor 1997). This concern was shared by students of Third World security, who maintained that Western-oriented, state-based approaches to security were unable to address the security needs and interests of states as well as nonstate actors in the Third World. These Western approaches focused on East-West stability and its maintenance through nuclear deterrence and nuclear power balancing, whereas Third World states sought to reject the automatic categorization of their problems into an East-West framework.

\section{Third World Security Approaches}

Students of Third World security have criticized the almost exclusive focus on crises and conflicts that has comprised the established (Cold War) ways of thinking about security. They are concerned about the neglect of longitudinal security processes - the processes of development through which the security of individuals and social groups are maintained (Al-Mashat 1985). Galtung's stress on the structural causes of insecurity struck a chord with Third World policymakers in an era marked by the formation of the nonaligned movement, the Group of 77, and calls for a New International Economic Order at the United Nations. The nonaligned movement emphasized the differences between their security agendas and that of the superpowers. The ideology of the movement constituted a fundamental challenge to mainstream thinking at the time. 
During the 1980s, some students of Third World security took up these issues once again (see, for example, Thomas and Saravanamutu 1989; Sayigh 1990). Caroline Thomas (1987) differentiated between two approaches to security. The first approach was adopted by those states in the developed world that were relatively satisfied with the status quo and saw security mainly in terms of its maintenance. They privileged the stability of the existing system as a foremost security concern. The second and more holistic approach, argued Thomas, was adopted by those states in the Third World that included economic, political, and environmental issues in their security agenda. The search for security in the Third World was mostly about maintaining domestic security through state-building and establishing secure systems for dealing with food, health, money, and trade as much as it was about building up the military. Accordingly, many (but not all) Third World states saw a change in the status quo not necessarily as a threat but rather as conducive to security-provided, of course, that the change was toward the creation of an international economic structure sensitive to the needs of developing states.

Although the distinction Thomas drew between the security needs and the interests of developed and developing states is helpful, the reader should note that not all developing states were against the status quo. Indeed, it was not always the case that Western conceptions of security were top-down, whereas those of the Third World were bottom-up. Rather, there were both developed and developing states (and nonstate actors) among those that propagated top-down views of security. For instance, when some Third World policymakers spoke of the need to address the nonmilitary dimensions of insecurity, they often meant the need to put limits on the exercise of democratic freedoms for purposes of state consolidation. The practical implication of this state-based approach to security was the government's domination over society in which the public's sacrifices were viewed as obligations. The state's privileges, in turn, were justified as being necessary to its survival. Accordingly, those who dared to challenge the security practices of their states and focused on individual or societal dimensions of security were marginalized at best; they were accused of treachery and imprisoned at worst.

Bottom-up views of security voiced by nonstate actors in the Third World did not get heard unless the groups adopted violent practices in an attempt either to form a state (as the Palestine Liberation Organization did) or to capture state power in their own countries (as the Muslim Brotherhood and Hezbollah did). The efforts of groups, like the Islamic Salvation Front (FIS) in Algeria, that undertook grassroots activism during the 1980 s by setting up a network of medical clinics and charitable associations to serve the poorest and most crowded localities not reached by the government were clouded by the violent practices that characterized most of their activities in the period following the 1991 elections.

However, some significant exceptions to this generalization exist. Gandhi captured the world's attention as well as its sympathy during the period that preceded India's independence (see Barash 2000). More recently, the Zapatistas have been successful in getting their voices heard through mostly nonviolent means. They chose to represent the enormous poverty and misery the Chiapas have gone through by adopting the language of the anti-globalization movements around the world. By timing their demonstrations for the day of the beginning of the North American Free Trade Association (NAFTA), the Chiapas successfully pointed to the detrimental effects of globalization in general and to its impact on indigenous peoples in particular (Ejército Zapatista de Liberación Nacional 2002).

Much of the critical thinking (and practices) surveyed above remained on the margins throughout most of the Cold War. Critics of Cold War security thinking were themselves criticized for their normative or political approaches to international phenomena (Bilgin 1999). Only in the post-Cold War period have these issues been revived once again by students of security who seized on the 
opportunity presented by the disappearance of the Soviet threat to broaden the security agenda and to point to threats faced by individuals and social groups.

\section{Post-Cold War Revival in Security Thinking}

The end of the Cold War provoked a long overdue interest in rethinking commonly held assumptions as well as practices concerning security (see, for example, Baldwin 1995; Tickner 1995). The 1990s witnessed a proliferation of works that focused on the individual and societal dimensions of security (for example, Buzan 1991; Sorensen 1996; Bilgin, Booth, and Jones 1998; Buzan, Waever, and Wilde 1998; Krause and Williams 1998). Academics who were critical of established ways of thinking about security called for dropping the traditional assumption that security could be understood and practiced within an interstate framework. Post-Cold War approaches turned toward frameworks that looked at the threats faced by nonstate actors (individuals, social groups, the global society) as well as states. Arguments were made that "International Security" might no longer be the best label for a field reconstructed as such. Because the word "international" suggests an interstate framework that is no longer the locus of the security problems faced by many actors around the globe, the phrases "global security" and "world security" were proposed as alternative formulations.

In the post-Cold War era, the academic debate on security was accompanied by practitioners' increasing interest in "human security," which in turn was warranted by a series of developments that were visible during the Cold War but became more apparent in its aftermath. These developments included (a) growing disparities in economic opportunities both within and between states; (b) increasing hardships faced by peoples in the developing world who found themselves on the margins of a globalizing world economy; (c) diminishing nonrenewable resources leading families and groups to become refugees; (d) rising anti-foreigner feelings and violence in reaction to migration pressures from the developing to the developed world; and (e) proliferating intrastate conflicts increasing public interest in, and pressure for, humanitarian intervention. Furthermore, it was not only an increase in public awareness of the aforementioned developments but also growing consciousness of the costs incurred as a result of the kinds of security practices produced by the established ways of thinking that provided the impetus for an alternative approach.

In the post-Cold War era, a range of actors including academics, the United Nations, and nongovernmental organizations explored individual and societal dimensions of security. What follows is a discussion of the key issues and approaches that arose during the 1990s.

\section{Whose Security?}

In the post-Cold War era, academic studies on security took a more sociological approach than before. In a pathbreaking article, Ken Booth (1991) questioned whose security existing approaches were designed to address. Depending on the referent, security analyses point to different threats and prescribe different solutions. For example, from the perspective of a superpower concerned with the maintenance of its regional and global interests in the post-September 11 environment, it is the so-called rogue or failed states that constitute the major threat to international security because they can provide hideouts to terrorist networks (National Security Strategy of the United States of America 2002). In effect, state failure has found itself a place on top of the US security agenda in the aftermath of the September 11, 2001, attacks. Previously, failed states were considered to be problems only when their situation became acute enough to threaten the world beyond their legal boundaries. Failing states, whose leaders adopted an 
anti-Western stance in an attempt to alleviate problems with domestic cohesion by diverting attention away from their internal problems to those involving foreign and security policy (as Iraq did in 1990), were labeled rogue states, and the problem was addressed accordingly (Bilgin and Morton 2002).

Consider US President George W. Bush's (2002) definition of the main threat to international security as the "the axis of evil," which comprises three countries - Iraq, Iran, and North Korea - represented as "outlaw regimes that possess and are developing chemical, biological, and nuclear weapons as well as the missiles to deliver them." These three countries, according to President Bush, are viewed as constituting a threat to international security not only because of their destructive potential, but also because of their support for international terrorism and the repression of their own people. From the perspective of peoples in the region, however, who took to the streets to demonstrate against US policies toward Iraq and Israeli policies toward the Palestinians, it is human rights violations, economic injustice, and political oppression that constitute the major threats to their security. Indeed, from the perspective of a Saudi woman, it might not be an Iraqi weapon of mass destruction program but her own government's policies that lower her life expectancy. From the point of view of Egyptian schoolchildren, the accumulation of weapons systems threatens their security primarily by directing valuable resources away from their education and their families' health care.

The stark contrast between the security interests of governments and individuals - the so called "scuds versus butter" dilemma all Middle Eastern governments must face (Sadowski 1993) - is also voiced by Moroccan author, Fatima Mernissi (1992:169), who has asked: "How can Arab women hope to overcome opposition in their societies and go out in search of paid work if the economies of their countries are devoting a large part of their wealth to unproductive expenditures like the importation of weapons that don't even serve any useful purpose, as the Gulf War amply demonstrated?" Viewed through her lenses, those extra-regional governments who sell the weaponry, those regional governments who give high priority to regime security and invest in the military, and those individuals and social groups who dare not challenge the status quo out of fear of the changes that democracy and human rights may introduce into their daily lives could all be considered partners in this crime committed against individuals' security. In sum, the simple question "whose security?" has provoked a lively debate on whether individuals should replace states as the primary referent of security.

\section{Individuals as the Primary Referents of Security}

Assessing the differences between individuals' and governments' security concerns, Booth (1991) argued that individuals' security should come first. In advancing his case, he made three interrelated points. First, states cannot be assumed to act as providers of security at all times because some are willing to make significant portions of their population insecure in an attempt to secure themselves (for example, the Iraqi government that violates the human rights of its own people), and others fail to respond to the needs of their citizens (for example, Somalia). In other words, the security of the state is not necessarily synonymous with that of the people who live within its physical boundaries. Second, even those states that fit the textbook definition by standing guard over their populace are generally doing so as a means to an end, not as an end in itself. Third, and finally, differences among states in both character and capacity make them unlikely to engage in a comprehensive approach to security. Indeed, state-based approaches to security do not allow us to examine the insecurities of individuals and communities within state borders, thereby glossing over a range of suffering in security analyses. 
Martin Shaw (1993) responded to the question of whether the state or the individual should be the primary referent of security by arguing that our options need not be limited to two: the state or the individual. He maintained that we need a complex and multilayered analysis of a variety of referents including social groups and the global society as well as individuals and states. In making this point, Shaw emphasized the need to develop an understanding of the dynamic relationships in which these potential referents interact and affect each other's security. In other words, he advocated that "social relations" was the missing dimension in the security debate.

This point was taken up by Bill McSweeney (1999) who maintained that security policies could not be formulated simply by aggregating individual needs or by attributing such needs to states. Rather, he made a case for a "reflexive theory of social order" that views the analysis of security as a dynamic process in which identities and interests are mutually constituted by social agents in search of security. Thus, McSweeney's proposed framework looked at individual human beings and communities not only as referents (whose security we should be concerned with) but also as agents who seek to enhance their own and others' security. This framework enabled him to understand how individuals and communities interact, and how new and broader communities are constructed as solutions to security problems through the manipulation of identities and interests by purposeful social agents (as with the formation of the European Union and the attempts to bring peace to Northern Ireland).

\section{Security as Emancipation}

Booth's (1991) proposed solution to the current state of insecurity was to develop a framework that did not simply reproduce existing threats (as when containment policies produce rogue states and, in worst case scenarios, become self-fulfilling prophecies). Specifically, Booth (1991:319) placed human beings at the center and gave priority to human emancipation:

\footnotetext{
"Security" means the absence of threats. Emancipation is the freeing of people (as individuals and groups) from those physical and human constraints which stop them carrying out what they would freely choose to do. War and the threat of war is one of those constraints together with poverty, poor education, political oppression, and so on.
}

Booth substantiates his argument by asserting that emancipation is in the spirit of our times, as witnessed by the end of the Cold War and the end of apartheid in South Africa as well as the progress in struggles that are still in progress (for example, in Israel-Palestine and Afghanistan).

Mohamed Ayoob (1995) responded to Booth's call for adopting an emancipationoriented approach by observing that such a practice would amount to imposing a model originating in the West onto Third World contexts. Ayoob (1995:11) argued that Third World states are the opposite of those found in the Western world that have "largely solved their legitimacy problem and possess representative governments that preside over socially mobile populations that are relatively homogenous and usually affluent and free from want." Accordingly, he called for continuing to give highest priority to the security needs and interests of states and regimes in the Third World.

Although it goes without saying that major differences occur between the security needs of different types of states, emancipation — as defined by Booth (1991) — is not an added extra that can only be sought in those Western polities that are presumably free from want. On the contrary, emancipation is understood as a process through which security is sought; it is a goal that is kept on the horizon 
during state-building and the making of security policy. Thus, the need for strengthening existing state mechanisms in the Third World should not be made an excuse for marginalizing individuals' and social groups' needs. The challenge for emancipation-oriented approaches to security is to find a way of addressing the security needs and interests of a variety of referents at different levels (see Bilgin, Booth, and Jones 1998).

When adopting an emancipation-oriented approach to the study of security, one confronts the problem of trying to define what emancipation means in different parts of the world (Pasha 1996). Even well-intentioned efforts could be viewed as adopting a patronizing attitude toward peoples of other cultures. Suggesting that issues such as human rights or the provision of basic education and health care should be a part of the security agenda could be taken as a claim to know peoples' real interests better than they themselves do. However, presenting citizens with choices that have been obscured by state-based approaches to security may also be interpreted as a claim to know what peoples' real interests are. Given the ways in which dominant discourses have shaped security agendas, one could reasonably assume that regional security agendas could have been set up differently had other (individual and societal-focused) discourses come to prevail.

\section{Insecurity Dilemma}

The security predicament of individuals and social groups was also pointed out by Brian Job (1992) who observed that the security environment of the majority of the world's population did not improve with the end of the Cold War and the disappearance of the superpower conflict. Indeed, people in the developing world, who constitute a significant portion of the globe's population, continue to suffer gross injustices, often at the hands of their own governments. According to Job, simply criticizing governments or pointing to societal insecurities is not going to help students of security understand this complex problem. The security dilemma of Third World states is often rooted in their colonial past and currently sustained by the international system. Hence, a need exists for an alternative framework that can provide a better analytical handle on the security problems of peoples in the Third World. This framework, Job believed, could be built around the concept of "insecurity dilemma."

Job's (1992) argument is that the security dilemma metaphor hinders more than it reveals when used within the Third World context. The security dilemma is premised upon the distinction between what goes on within and what goes on outside a country. It assumes that the inside of the state is safe and that threats come from outside state boundaries. However, this inside-outside distinction makes little sense in the Third World where international boundaries are safeguarded by the constitutive norms of international society (namely, sovereignty, the nonviolability of borders, and nonintervention) whereas domestic threats dominate governmental security agendas. In such cases, the concept "insecurity dilemma" provides an enhanced understanding of the difficulties faced in the Third World where "states are preoccupied with internal rather than external security, and weak states have a guaranteed existence in what is supposedly an anarchic international system" (Job 1992:18). Accordingly, Job called for a more comprehensive framework to understand the insecurities faced by individuals and social groups - a framework that would allow students of security to understand the ways in which security problems in the developing world are created by the developed world and sustained by the norms and institutions of international society.

Job's argument is in contrast to that of Ayoob (1995) who stresses the primacy of political-military considerations in the developing world and has called for us to give the highest priority to the needs and interests of these states until governmental mechanisms become strong enough to allow them to compete with 
other states. Following Job, one could point to a number of problems involved in adopting such policies. First, strengthening the mechanisms of states that often turn their machinery against their own people amounts to neglecting the security concerns of individuals and social groups. Second, trying to strengthen state mechanisms in a world constantly being reshaped by the forces of globalization and fragmentation represents an enormous challenge. Third, attempting to strengthen state mechanisms without raising the awareness of international actors regarding their complicity in the current condition of Third World states is likely to prove futile. Similar problems have been raised by the critics who have called for rethinking the institutions and norms of global governance to tackle the insecurities of peoples in the developing world (see the section below on human security).

\section{Societal Security}

"Societal security" is another concept designed to address the limitations of existing conceptual tools in analyzing contemporary developments. Societal security as a concept grew from debates about security in Europe in the post-Cold War era. It was developed as a conceptual approach by a group of scholars affiliated with the Copenhagen Peace Research Institute (Waever et al. 1993) whose research was stimulated by developments unleashed by the end of the Cold War and the dissolution of the Soviet Union. They were concerned that "nation" and "state" do not mean the same thing in a majority of countries around the world and that "national security" is becoming an increasingly irrelevant framework with which to study post-Cold War developments in Europe. In its stead, they proposed the term "societal security" and a focus on the insecurities of societies-understood as national, ethnic, or religious communities.

Established understandings of security have assumed state and society to be synonymous. The tension between the security needs and interests of the state and of the society is resolved by assuming that the state, the society, and the nation are one and the same. Post-Cold War developments such as the ethnic separatism and cleansing in Yugoslavia and the emergence of domestic resistance to the expansion of the European Union have demonstrated, however, that the security needs and interests of the state and society do not always coincide. When there is a clash of interests between the two (as with the anti-European sentiments being raised in various EU member states) or competing claims to sovereignty within the same state (as in the former Yugoslavia), the "national security" framework is not very helpful as a guide for the study and practice of security (see, for example, Posen 1993). In such conflicts, what is secured is an idea, a "we" feeling. Society becomes the subject of security.

Ole Waever (1993:23) defined societal security as the "ability of a society to persist in its essential character under changing conditions and possible or actual threats. ... the sustainability, within acceptable conditions for evolution, of traditional patterns of language, culture, association, and religious and national identity and custom." The break-up of the former Yugoslavia is often used to illustrate how such societal insecurities can lead to violent conflicts (see, for example, Wiberg 1993). Although the 1991 crisis in Yugoslavia had a number of causes (including economic decline, constitutional conflicts, and ethnic discord) that had been glossed over by the communist regime, it is argued that the effective cause was the competing societal identities of the Croats, Serbs, and Slovenians (Ramet 1996). Following the end of the Cold War, each of these groups chose to view each other's identity as the threat in an attempt to strengthen their own sense of who they were, thereby giving rise to a dynamic that resembles the security dilemma. The difference between this process and the classic security dilemma is that instead of threatening each other by building their militaries, the constituent societies of the former Yugoslavia threatened each other by emphasizing the dominance of their 
identities. This method of using ethnonational symbols to strengthen the idea of nationhood ("we" feeling) among one's own populace led to neighbors feeling threatened and, in turn, adopting similar policies to strengthen their own identity. The wars that resulted in the break-up of Yugoslav indicate the ways in which security and identity dynamics interact.

In the case of the former Yugoslavia, it was different societal groups that viewed each other as threatening. In some other cases, it is state action itself that is viewed as the source of societal insecurity. Take, for example, the case of the European Union during the 1990s. As European integration gained pace, a growing divergence between the security concerns of communities and governments emerged. Some viewed the push for integration at the governmental level as jeopardizing the economic and cultural interests of different parts of their societies (for instance, French farmers protesting against European agricultural products or the British hesitancy to drop their national currency and adopt the euro). The government's pro-European Union stance gave rise to societal insecurities-hence, the need to develop an understanding of the different priorities demanded by a state focus (sovereignty) versus a society focus (identity).

The European Union case also demonstrates how policymakers respond to societal insecurities that are caused by changing patterns of international migration and the rising interest in and sensitivity to the security dimensions of refugee movements (Buzan 1993). During the 1990s, migration became a concern not just for North America and Oceania (regions that have been receiving migrants for a long time) but for almost all countries of the world. It is estimated that by the end of the 1990s, more than two percent of the world's population was living outside their country of birth (Poku and Graham 2000). The ensuing mix of populations has given rise to paranoia and xenophobia in some countries, as evidenced by the rise of the far right in Austria, Belgium, Denmark, Italy, the Netherlands, and more recently France.

In particular, the export of security issues from home to host countries has turned migration into a security problem for EU policymakers in the post-Cold War era (Bilgin forthcoming). The rise in the levels of crime and disorder are often blamed on immigrant populations even though research has shown that these groups have no higher rates of crime than the host populations (Graham 2000). Furthermore, growing unemployment in the European Union has fueled anti-immigrant feelings among the unemployed. The difficulties involved in meeting the educational and social needs of members from a different culture have created further problems. All these issues have became rallying points for radical groups and conservative political parties in the member states of the European Union. Governments that were late in recognizing the increase in these feelings found themselves at odds with their populace. They faced the dilemma of having to choose between adopting restrictive anti-immigrant regulations (and risk being criticized for antidemocratic and antihuman rights practices) or accepting low-skilled immigrants from other cultures (and enduring the criticisms of the conservatives about weakening the social fabric of their society).

Consider, for example, the leader of the National Front in France, Jean-Marie Le Pen, whose presidential campaign capitalized on popular concerns about crime and immigration. He took 17 percent of the vote in the first leg of the French presidential elections and came second only to the leader of the center-right, Jacques Chirac. Arguably, the rise of the far right in France is a phenomenon that can be explained with reference to societal insecurity. Social groups in France who felt threatened by crime and immigration (as well as the loss of jobs) were led to view these issues as threats to their identity. It is in this sense that the concept of societal security helps us understand under what conditions societies may become significant as political actors. Furthermore, by examining societal security, we are 
able to discern how societal identities can arise that are independent of the state and in reaction to the identity the government seeks to emphasize.

Having made these points, one can also point to a number of difficulties with giving high priority to the insecurities of societies, especially for policy purposes. First is the problem of having to judge the competing identity claims of different national, ethnic, and religious groups. When Bosnians, Serbians, and Croatians perceive threats to their identity as the cause of the conflict over BosniaHerzegovina, how do we decide who is the aggressor and who is the victim? After all, the societal security dilemma metaphor suggests that all parties are victims. Yet, as the debates of the early 1990s regarding whether or not to intervene into Bosnia showed, an inability to answer this question delayed much needed humanitarian action.

Second, when societal security is used to guide policy, society becomes reified and treated as constant and unchanging. Such a fixed conceptualization is a problem because the main contribution of societal security as an alternative approach to thinking about security results from the attention paid to the ways in which society constitutes itself in an attempt to secure its identity. To deal with this problem, the concept of societal security needs to allow for a more fluid notion of society - as a process of negotiation, affirmation, and reproduction-instead of as an objective reality or independent variable. Along these lines, McSweeney (1999) has proposed that we refuse to privilege claims to separate identity in security analyses: "the security problem is not there just because peoples have separate identities; it may well be the case that they have separate identities because of the security problem" (McSweeney 1999:73, emphasis in the original). Thus, clashes over identity are not the cause but the outcome of a process through which conflicts over economic and political interests are reframed and presented in terms of identity.

Following McSweeney, the concept of societal security should be further developed to allow students of security to understand how societies create and re-create their identities and interests through practice. Such an approach would allow us to understand how people, who have lived side by side for years, could turn against each other and define their neighbors as the source of their societal insecurity - as in Bosnia-Herzegovina during the 1990s. It would also help us learn how people who fought two world wars in less than fifty years could choose to redefine their identities and interests in a way that permitted them to construct a security community - as in Western Europe in the aftermath of World War II (Waever 1998).

\section{Human Security}

The concept of "human security" emerged out of the recognition that individuals and communities' security does not necessarily follow from the security of the state in which they are citizens. On the contrary, the genocidal records of some states and the gross injustices in the distribution of resources in others suggest that states can constitute a major threat to their own citizens' well-being. If governments fail to cope with persistent poverty and illiteracy, their policies become a source of insecurity by lowering people's life expectancies and decreasing their opportunities. Such practices have caused experts to suggest that in some parts of the world the bedrock assumption of security, namely that what goes on inside the state is peaceful and what goes on outside is anarchic, has been turned on its head. As Robert Jackson (1992:93) has maintained, "instead of states or alliances defending their populations against external threats, international society is underwriting the national security of states, whether or not they convert it into domestic security for their citizens."

An early recognition of the difficulty of reconciling the needs and interests of states with that of individuals and social groups was noted in the Report of the 
Commission on Global Governance (1995:22-23) titled Our Global Neighborhood. The commission maintained that the security of states and individuals should not be viewed as mutually exclusive in that "states cannot be secure for long unless their citizens are secure." Thus, the commission's recommendation favored upholding the right of states to security while at the same time making the protection of people and their security one of the aims of global security policy.

This dual focus in the wording of the commission is in contrast with the United Nations Development Program's (UNDP) (1994) Human Development Report. The UNDP report pointed out two ways in which the concept of security should be changed: (1) the stress put on territorial security should be shifted toward people's security, and (2) security should be sought not through armaments but through sustainable development. The report made four points concerning the need to move away from a national security approach toward an approach that emphasizes human security. First, the authors of the UNDP report presented human security as a universal concern that is relevant to people across the world regardless of geographical location. The process of globalization has created a third world within the first world as well as a first world within the third world. Second, the report maintained that the components of security are interdependent; distress in one part of the world is likely to affect other parts of the world. Third, human security is best ensured through prevention rather than intervention after the crisis takes its toll. Fourth, the report argued that the referent for security (that is, the focus for security thinking and practices) should be the people rather than states.

This fourth point is the most radical as far as the history of the United Nations is concerned. After all, the need to adopt a more people-based approach to security was recognized early by the founders of the United Nations. According to the United Nations Development Program (1994:24) report, after the San Francisco conference that set up the United Nations, the US Secretary of State reported to his government that:

\footnotetext{
The battle for peace has to be fought on two fronts. The first is the security front where victory spells freedom from fear. The second is the economic and social front where victory means freedom from want. Only victory on both fronts can assure the world of an enduring peace. . . . No provisions that can be written into the Charter will enable the Security Council to make the world secure from war if men and women have no security in their homes and their jobs.
}

The difference between this statement from the 1940s and the one from the 1990s is that in the former the central concern for practitioners was the achievement of enduring peace understood as stability. Accordingly, individual human beings' security was viewed as important insofar as it threatened international stability. Although in the 1990s, the United Nations still gives priority to enduring peace, its human security approach is designed to ensure that an international economic breakdown (such as the one in the 1930s that preceded World War II) does not recur. Moreover, the authors of the UNDP report are more open in urging a move away from a state-centric approach that seeks peace understood as stability toward a people-centric approach that seeks peace through change (however incremental it may be).

Thus, the UNDP report is clearer than that of the Commission on Global Governance (or the founders of the United Nations) as to whose security they ascribe utmost priority. More recently, the Secretary General of the United Nations, Kofi Annan (1999), also embraced human security as a strategic guide to action and pointed to the existing conception of state sovereignty and the narrow and often self-centered definition of national interest as obstacles to effective action for human rights in humanitarian crises. Annan introduced the concept of "individual sovereignty" to try to deal with the first of these obstacles. Individual sovereignty 
comprises the human rights and fundamental freedoms of each and every person as already enshrined in the United Nations Charter. With reference to national interest, Annan (1999) is quoted as having said, "in a growing number of challenges facing humanity, the collective interest is the national interest." For the United Nations, then, human security is a strategic term used to direct attention to humanitarian crises whose daily death toll shames humankind into action.

Annan and others who discuss human security have not yet given us a formal conceptualization of the term nor attempted to bring an order to existing definitions (see Suhrke 1999). Rather, human security is used as a slogan to emphasize the need for intervention when governments - for reasons of national security - withhold action. In this sense, Annan and others have tried to make use of security as an evocative term to direct attention to problems faced by individuals and social groups during humanitarian catastrophes.

While holding the presidency of the United Nations Security Council, Canada put the issue of human security on the agenda - a first in UN history (Suhrke 1999: 266; See also Axworthy 1977). The United Nations had discussed the issue of violence against civilians during armed conflict many times before, but never had humanitarian principles and the issue of intervention been opened to such a universal discussion. This change in the UN approach was not only enabled, but necessitated by the end of the Cold War. It was enabled in the sense that, during the Cold War, intervention into political conflicts was considered a high-risk venture because of the superpower rivalry. The possibility was always present that an interstate conflict could escalate into a superpower conflict. The end of the Cold War removed such fears. The end of the Cold War also necessitated consideration of human security because the end of the superpower rivalry meant the cessation of superpower interest in conflicts in far away places that did not necessarily impinge on their national interest. For these reasons, intervention on humanitarian grounds emerged as an effective alternative to the previous approaches.

In addition to the United Nations, Canada and Norway also have taken up human security as a foreign policy tool - an act reminiscent of the 1960s CanadianNorwegian cooperation on UN peacekeeping issues. Indeed, during the 1990s human security emerged as a strategic way to bring together a variety of actors with, at times, diverse interests. For Canada, human security has provided a strategic rationale for maintaining a certain level of military force deemed critical by the Ministry of Defense. The concept has also enabled the Canadian government to polish its image as a "soft power" - an image created by Canada's active participation in international peacekeeping efforts. Similarly, observers have viewed Norwegian advocacy of human security as a search for "humanitarian great power status" (Suhrke 1999).

As defined by the Canadian and Norwegian governments, human security includes human rights and international humanitarian law as well as socioeconomic development based on equity. The latter does not appear on the UN's humanitarian agenda, focusing as it does on issues related to intervention. For other countries, such as Jordan, human security provides a buzzword to repackage and put on the international agenda the age-old dilemma of having to choose between channeling resources into the military or using them in the civilian sector. Jordan for a long time has called for a region-wide effort to end the Middle East's arms race. In 1991, Jordanian policymakers proposed to link debt reduction and arms control (the so-called arms-for-debt proposal) in an attempt to break out of the vicious circle: debt breeds poverty, poverty fuels violence, violence stimulates competitive arms purchases, which in turn increase foreign debt (Sadowski 1993). Notwithstanding the appeal of an arms-for-debt swap for many governments, the proposal was overshadowed by the breakthrough in Israeli-Palestinian negotiations in Oslo. In this sense human security can be viewed not only as a global template on which to reshape various actors' security policies and 
interests but also as a strategic tool for actors to use in pushing forward their own, often domestic, agendas.

Changing the primary referent of security from states to human beings has implications for understanding the sources of threats and formulating policies to cope with those threats. Although human security may serve as a useful strategic tool for some policymakers to bring their own priorities to the world's attention, finding solutions to such problems requires action at the global level. Yet, global governance institutions are often perceived by peoples in the Third World as biased and Western in orientation. As Thomas (2001) has argued, putting a human security approach into practice requires taking steps toward democratizing global governance, which in turn involves moving toward more inclusive, bottom-up, and participatory politics. This point raises the question: "Who are the agents of security?"

\section{Agents of Security}

Thomas (2000) considers the involvement of civil society actors in reviewing and democratizing global governance as a must. Indeed, it is worth qualifying Booth's statement quoted above ("states should be treated as means not ends") by observing that states should be treated as means, but not the only means. Yet, established ways of thinking about security remain oblivious to the potential that nonstate actors have as agents of security (Bilgin 2002).

The prominence of the state's agency in the economic and financial sectors has long been challenged, but it has yet to be dethroned in certain types of security matters. There are a number of reasons for this problem. First, states have a monopoly over the legitimate use of violence in international society. Second, they are considered well equipped to meet threats to security. Third, our analytical lenses have become conditioned to focus on states in the analysis of security. Because established ways of thinking about security have been state-based, external-directed, and military-dominated, students of security have privileged the state as agent in their analyses. But the record of the last fifty years shows that states are increasingly less able to provide for their security on their own. Indeed, they have resorted to military alliances or collective security organizations to cope with threats of a military nature. The recognition of such limits to the state's agency requires fresh answers to the question of who are the agents of security.

Although established ways of thinking about security do not have much to say about the agency of nonstate actors, the latter have challenged the security agendas set up by governments for a long time. Indeed, the organized actions of nonstate actors have been referred to as "foreign policy from below" or "grassroots statecraft" in the literature (see Marsh 1995). One can distinguish between four different forms of action. Some actors seek to alter the policies of foreign governments by getting their own government to exert pressure, such as the antiApartheid movement that sought to change the US government's policy toward South Africa in an attempt to end apartheid. Other actors directly intervene in the affairs of a foreign government, as do Amnesty International and Human Rights Watch. Also consider those individuals that cross borders to form organizations that are transnational in character. Greenpeace is a good example of such an organization. And, finally, some individuals challenge their government's policies as well as the global security agenda (see, for example, the actions of the women of Greenham Common described below).

The point is that a broader security agenda requires us to look at the activities of agents other than the state, such as social movements, nongovernmental organizations, and transnational citizens. Such an examination is essential not only because states are not always able or willing to fulfill their side of the bargain in providing for their citizens' security, but also because agents other than states are 
already striving to provide for the differing needs of peoples (themselves and others).

\section{Twenty-First Century Security in a Risk Society}

It is often suggested that a major source of current insecurities is rooted in a certain lack of imagination among power-holders around the world. Established ways of thinking about security have so far hindered attempts to move away from states as the primary referents and agents of security. Thus, a change in mindsets is required to become fully aware of the importance of the individual and societal dimensions of insecurity and to take remedial action.

Another source of humanity's current insecurities is a lack of self-reflection; that is, people remain unaware of the ways in which they themselves constitute their own threats. Ulrich Beck $(1992,1999)$ has explored this phenomenon in his work on the "Risk Society" and has presented us with a new framework within which to analyze social change and its security implications.

\section{Risk Society}

Risk is defined by Beck (1999:21) as "a systematic way of dealing with hazards and insecurities induced and introduced by modernization itself." Modern industrial society has manufactured and perpetuated its own risks by defining and calculating acceptable levels of risk. Viewed as such, risks emanate not only from sources that are beyond human beings' control (such as earthquakes), but they are also humanmade insofar as they are rooted in the knowledge produced by experts worldwide (such as environmental pollution). Beck (1999:6) explains his argument with reference to the risks created by the prevalence of neoliberal economics:

\footnotetext{
The past decade has shown that the dogmatic free-market economics imposed throughout the $1980 \mathrm{~s}$ - and to which every world and national forum has since signed up - has exacerbated environmental risks and problems just as much as central planning from Moscow ever did. Indeed free-market ideology has increased the sum of human misery. On the back of crucial free-trade pacts like the WTO and NAFTA, for example, consumption is now virtually out of control in the richest countries. It has multiplied six times, according to the UN. The richest 20 per cent of the people are consuming roughly six times more food, energy, water, transportation, oil, and minerals than their parents were.
}

These are human-made risks, manufactured by deciding what is controllable and what is beyond control. The latter are treated as threats that need to be met through emergency measures whereas the former do not enter the security agenda. We, as human beings, are aware of the dangers involved in a free-market economy (as demonstrated by the Asian financial crisis of the 1990s), yet we regard them as controllable. Thus, our own definitions and scientific calculations define what are viewed as acceptable levels of risk in our societies.

Framing the future of nuclear weapons in contemporary world politics provides us with a way to illustrate this process of manufacturing risks. Policymakers in the nuclear powers have so far made use of state-based conceptions of security to gloss over the serious risks involved for their citizens in the production and stockpiling of nuclear weapons. In a manner rather oblivious to the threats to the security of individuals and communities, it has been (and still is) argued that nuclear weapons are the ultimate weapon for maintaining international security. It is further argued that the advent of nuclear weapons enhanced security during the Cold War. At the root of such arguments is an external-directed and state-based conception of security. Nuclear weapons are viewed as tools with which to manage risks that emanate from outside a country's boundaries. Their implications for those inside 
those borders are often neglected. Yet, the production and stockpiling of nuclear weapons threaten the lives of the people who are directly involved in the process.

The exact costs of the Cold War nuclear arms race on the people who were involved in weapons production in the United States and the Soviet Union is still not known. Nor do we know the costs incurred by those who lived near nuclear weapons facilities, or by uranium miners. Still, thanks to archival research, we now have some ideas concerning how often the world came to the brink of nuclear catastrophe during the Cold War, as part of attempts to maintain international security understood as stability in superpower relations. In other words, the very same weapons that were designed to maintain security have led to insecurities for those who participated in their production or stockpiling as well as for the rest of the world's population who did not know how fragile nuclear command and control systems really were (Sagan 1993; Lopez and Myers 1997). Thus, following Beck, it could be argued that policymakers have considered these kinds of threats, directed against the security of people (as individuals and communities), controllable in order to render acceptable the dangers involved in continuing to produce, stockpile, and oversee nuclear weapons. In other words, these risks were considered appropriate because they were deemed necessary to defend the world against greater threats (that is, those risks that were viewed as uncontrollable).

A concrete example of this phenomenon was witnessed during the 1980s when the British government agreed to the US request to place cruise missiles in Britain. The women of Greenham Common reacted by challenging this state-based approach to security and pointing out the human costs involved (see Sylvester 1994). In 1981, women marched 110 miles from Cardiff in Wales to Greenham Common in Bekshire to protest against the NATO decision to site cruise missiles at the Royal Air Force base located there, which had become a base for the United States Air Force. On arrival, the women set up their Peace Camp outside the main gate of the base. Between 1981 and 1983, the protesters concentrated on disrupting construction work at the base by such acts as blockading the base and cutting down parts of the fence. In 1983 when the missiles arrived, so did women from all parts of the United Kingdom bent on ridding the Common of nuclear weapons and the military through nonviolent action.

The significance of the Greenham Womens' protest was partly due to its mastery of nonviolent techniques and partly due to the way they subverted the language of security and risk used by policymakers. For instance, one of the banners of the protesters read: "Take a risk for peace now." By way of this banner, the protesters indicated the human-made character of risks, that no 100 percent risk-free world is possible, and that policymaking regarding security always entails management of some risks. Another banner, which read "hospitals for today, not the day after," suggested the ways in which governments manage risks by emphasizing certain kinds of threats (that is, those posed against the security of the state) while putting off certain others (that is, those posed against the well-being of individuals).

The attempts of the Greenham Common women to emphasize the threats to people's security resulting from governmental policies can be understood within the framework provided by Beck. The difference between Beck's approach and that of traditional academic peace researchers (who have also emphasized individuals' concerns) is that Beck allows students of security to analyze the ways in which threats do not just exist "out there" but suggests how they are manufactured by human beings themselves. The implication is that individuals and social groups may challenge prevalent risk assessments made by governments and direct attention to their own insecurities.

Beck's general proposition is that what we are encountering in the contemporary era is the emergence of a worldwide risk society in which risks are distributed unevenly across the globe and that politics has become a major tool through which such risks are processed. According to Beck, it is not merely the omnipresence of 
risks that defines this risk society, but also the way it forces world politics to focus on risk management. The goal for a range of actors has become trying to foresee and control the future consequences of human action.

\section{"Take a Risk for Peace Now"}

Calls for addressing the individual and societal dimensions of security have been widely criticized. It has, for instance, been argued that shifting the focus away from states and military threats to individuals and their security is only desirable when threats such as the Iraqi weapons of mass destruction program no longer exist. But so long as they do, policies should be adopted to deal with them first. The argument goes that this type of threat has the potential to cancel out all other lofty concerns. This line of reasoning was prevalent in Western Europe (among other places) during the Cold War, and students doing peace research who called for rethinking the East-West relationship were often considered disloyal for failing to stand by their compatriots in the face of the Soviet threat.

This type of argument remains prevalent in the twenty-first century Middle East, where women (among others) are made to feel guilty for voicing their own security concerns at a time when the threat posed by Israel remains. In this sense, using military threats against state security to justify governmental neglect of the individual dimension of security in itself constitutes a threat to the security of individuals and social groups by making it more difficult for people to voice their concerns. Furthermore, although the events of September 11 could be used to show that traditional threats remain and need to be addressed, the same events can also be viewed as pointing to the need for alternative approaches that would deliver stable peace in Boulding's (1978) terms (Bilgin 2001). After all, terrorism (especially when used by those who have little to lose against those who have a lot to lose) is a threat for which no effective solution has yet been found.

In response to such criticisms, Booth (1999) has maintained that paying attention to the threat posed by weapons of mass destruction is a must so long as this focus does not lead to the neglect of other concerns that touch the lives of individuals. Understanding the differences between these two cultures of security-identified by Booth as the "culture of nuclearism" and the "culture of human rights" - has become the challenge for students of security in the twenty-first century:

\footnotetext{
Global nuclear war remains the possibility that could cancel out all other human possibilities. By contrast, a universal human rights culture is the possibility that could help reinvent all other human possibilities. This clash of cultures is at the heart of competing constructions of security, and is fundamental to the future shape of politics on a global scale. (Booth 1999:1)
}

The need to move away from a culture of nuclearism toward that of human rights becomes much more stark when viewed through Beck's (1999) conceptual lenses. After all, his framework could be used to show how nuclear responses (applauded within the culture of nuclearism) constitute the very dangers to which they purport to respond. It could further be used to emphasize the need for the participation of a variety of actors in managing risks - a process that Thomas (2000) labels "reviewing global governance." These actors would be expected to contest prevalent definitions of risk and manufacture others that are in line with their own perceptions of threat. For example, social movements would challenge governments' state-centric conceptions of security by pointing to individual and societal dimensions of security. Although not all kinds of actors in different parts of the world would have an equal say in this process, the need for having more transparency in decision making becomes apparent. By giving more priority to individual and societal dimensions of security, we begin to render visible the 
practices of both state and nonstate actors as they reflect upon the present and potential consequences of their own actions for international security.

\section{References}

Allison, Roy. (1991) New Thinking about Defence in the Soviet Union. In New Thinking on Strategy and International Security, edited by Ken Booth. London: HarperCollins.

Al-Mashat, Abdul-Monem M. (1985) National Security in the Third World. Boulder: Westview Press.

Annan, Kofi. (1999) Human Security and Intervention: Individual Sovereignty. Vital Speeches of the Day 66 (No. 1).

Axworthy, Lloyd. (1997) Canada and Human Security: The Need for Leadership. International Journal 52:183-196.

Ayoов, Монамmed. (1995) The Third World Security Predicament: State Making, Regional Conflict, and the International System. Boulder: Lynne Rienner.

Baldwin, David. (1995) Security Studies and the End of the Cold War. World Politics 48(3):117-123.

Barash, David P., ed. (2000) Approaches to Peace: A Reader in Peace Studies. Oxford: Oxford University Press.

Beck, Ulrich. (1992) Risk Society: Towards a New Modernity. Translated by Mark Ritter. London: Sage. Beck, Ulrich. (1999) World Risk Society. Cambridge: Polity.

Bilgin, Pinar. (1999) Security Studies: Theory/Practice. Cambridge Review of International Affairs $12(2): 31-45$.

Bilgin, Pinar. (2001) Alternative Futures for the Middle East. Futures 33:423-436.

Bilgin, Pinar. (2002) Beyond Statism in Security Studies? Human Agency and Security in the Middle East. Review of International Affairs 2:100-118.

Bilgin, Pinar. (Forthcoming) A Return to "Civilizational Geopolitics" in the Mediterranean? Changing Geopolitical Images of the European Union and Turkey in the Post-Cold War Era. Geopolitics.

Bilgin, Pinar, and Adam David Morton. (2002) Historicizing Representation of "Failed States": Beyond the Cold War Annexation of the Social Sciences? Third World Quarterly 23:55-80.

Bilgin, Pinar, Ken Booth, and Richard Wyn Jones. (1998) Security Studies: The Next Stage? Naçao e Defesa 84:137-157.

Bоотн, Ken. (1991) Security and Emancipation. Review of International Studies 17:313-326.

Bоотн, Ken. (1999) Nuclearism, Human Rights, and Constructions of Security (Part I). International Journal of Human Rights 3(2):1-24.

Boulding, Kenneth. (1978) Stable Peace. Austin: University of Texas Press.

Bush, George W. (2002) State of the Union Address. Available at www.whitehouse.gov/news/releases/ 2002/01/20020129-11.html.

Buzan, Barry. (1991) People, States, and Fear: An Agenda for International Security Studies in the Post-Cold War Era. New York: Harvester Wheatsheaf.

Buzan, BARry. (1993) Introduction: The Changing Security Agenda in Europe. In Identity, Migration, and the New Security Agenda in Europe, edited by Ole Waever, Barry Buzan, Morten Kelstrup, and Pierre Lemaitre. London: Pinter.

Buzan, Barky, Ole Waever, and JaAp de Wilde. (1998) Security: A New Framework for Analysis. Boulder: Lynne Rienner.

Commission on Global Governance. (1995) Our Global Neighborhood. Oxford: Oxford University Press.

Dunn, David J. (1991) Peace Research Versus Strategic Studies. In New Thinking on Strategy and International Security, edited by Ken Booth. London: HarperCollins.

Ejército Zapatista de Liberación Nacional. (2002) Available at www.ezln.org.

Galtung, Johan. (1969) Violence, Peace, and Peace Research. Journal of Peace Research 6(3):167-192.

Galtung, Johan. (1996) Peace by Peaceful Means: Peace and Conflict, Development and Civilization. London: Sage.

Garrison, Jim, and John Francis Phipps, with Pyare Shivpuri. (1989) The New Diplomats: Citizens as Ambassadors for Peace. Devon: Green Books.

Graham, David T. (2000) The People Paradox: Human Movements and Human Security in a Globalizing World. In Migration, Globalization, and Human Security, edited by David T. Graham and Nana K. Poku. London: Routledge.

Herz, John. (1950) Idealist Internationalism and the Security Dilemma. World Politics 2(2):157-180.

Independent Commission on Disarmament and Security Issues. (1982) Common Security: A Programme for Disarmament. London: Pan Books. 
Jackson, Robert H. (1992) The Security Dilemma in Africa. In The Insecurity Dilemma: National Security of Third World States, edited by Brian Job. Boulder: Lynne Rienner.

Job, Brian. (1992) The Insecurity Dilemma: National, Regime, and State Securities in the Third World. In The Insecurity Dilemma: National Security of Third World States, edited by Brian Job. Boulder: Lynne Rienner.

Kaldor, Mary. (1997) The Revolution of 1989. In Peace and Security: The Next Generation, edited by George A. Lopez and Nancy J. Myers. Lanham, MD: Rowman \& Littlefield.

Krause, Keith, and Michael Williams, eds. (1998) Critical Security Studies: Concepts and Cases. London: UCL Press.

Lopez, George A., And Nancy J. Myers. (1997) Peace and Security: The Next Generation. Lanham, MD: Rowman \& Littlefield.

McSweeney, Bill. (1999) Security, Identity, and Interests: A Sociology of International Relations. Cambridge: Cambridge University Press.

Marsh, Pearl-Alice. (1995) Grassroots Statecraft and Citizens' Challenges to U.S. National Security Policy. In On Security, edited by Ronnie D. Lipschutz. New York: Columbia University Press.

Mernissi, Fatima. (1992) Islam and Democracy: Fear of the Modern World. Translated by Mary Jo Lakeland. Reading, MA: Perseus Books.

National Security Strategy of the United States of America. (2002) Available at www.whitehouse. gov/nsc/nss.html.

Pasha, Mustapha Kamal. (1996) Security as Hegemony. Alternatives 21:283-302.

Poku, Nana K., And David T. Graham. (2000) Introduction. In Migration, Globalization, and Human Security, edited by David T. Graham and Nana K. Poku. London: Routledge.

Posen, Barry. (1993) The Security Dilemma and Ethnic Conflict. Survival 35:27-47.

Rabinowitch, Eugene. (1997) Scientists as Public Educators: 1945-1950. In Peace and Security: The Next Generation, edited by George A. Lopez and Nancy J. Myers. Lanham, MD: Rowman \& Littlefield.

Ramet, Sabrina P. (1996) Balkan Babel: The Disintegration of Yugoslavia from the Death of Tito to Ethnic War. Boulder: Westview Press.

Sadowski, Yahya. (1993) Scuds or Butter? The Political Economy of Arms Control in the Middle East. Washington, DC: Brookings Institution.

Sagan, Scott. (1993) The Limits of Safety: Organizations, Accidents, and Nuclear Weapons. Princeton: Princeton University Press.

SAYigh, Yezid. (1990) Confronting the 1990s: Security in the Developing Countries. Adelphi Papers No. 251 (Summer).

Shaw, Martin. (1993) "There Is No Such Thing as Society": Beyond Individualism and Statism in International Security Studies. Review of International Studies 19:159-175.

Sorensen, Georg. (1996) Individual Security and National Security: The State Remains the Principal Problem. Security Dialogue 27:371-386.

Suhrke, Astri. (1999) Human Security and the Interests of States. Security Dialogue 30:265-276.

Sylvester, Christine. (1994) Feminist Theory and International Relations in a Postmodern Era. Cambridge: Cambridge University Press.

Thomas, Caroline. (1987) In Search of Security: The Third World in International Relations. Boulder: Lynne Rienner.

Thomas, Caroline. (2000) Global Governance, Development, and Human Security: The Challenge of Poverty and Inequality. London: Pluto Press.

Thomas, Caroline. (2001) Global Governance, Development, and Human Security: Exploring the Links. Third World Quarterly 22:159-175.

Thomas, Caroline, and Paikiassothy Saravanamutu, eds. (1989) Conflict and Consensus in North/South Security. Cambridge: Cambridge University Press.

Tickner, J. Ann. (1995) Re-visioning Security. In International Relations Theory Today, edited by Steve Smith and Ken Booth. Cambridge: Polity.

United Nations Development Program. (1994) Human Development Report: New Dimensions of Human Security. New York: Oxford University Press.

Waever, Ole. (1993) Societal Security: The Concept. In Identity, Migration, and the New Security Agenda in Europe, edited by Ole Waever, Barry Buzan, Morten Kelstrup, and Pierre Lemaitre. London: Pinter.

Waever, Ole. (1998) Insecurity, Security, and Asecurity in the Western European Non-War Community. In Security Communities, edited by Emanuel Adler and Michael Barnett. Cambridge: Cambridge University Press. 
Waever, Ole, Barry Buzan, Morten Kelstrup, and Pierre Lemaitre, eds. (1993) Identity, Migration, and the New Security Agenda in Europe. London: Pinter.

Wiberg, Håkan. (1993) Societal Security and the Explosion of Yugoslavia. In Identity, Migration, and the New Security Agenda in Europe, edited by Ole Waever, Barry Buzan, Morten Kelstrup, and Pierre Lemaitre. London: Pinter.

Wheeler, Nicholas J., and Ken Booth. (1992) The Security Dilemma. In Dilemmas of World Politics: International Issues in a Changing World, edited by John Baylis and N. J. Rengger. Oxford: Clarendon Press. 